\section{Fludioxonil + Mefenoxam Seed Treatment Improves Edamame Seedling Emergence}

\author{
Martin M. Williams, $\mathrm{II}^{1,3}$ and Carl A. Bradley ${ }^{2}$
}

\begin{abstract}
AdDitional Index words. Glycine max, vegetable soybean, fungicide, soilborne pathogens

SuMMARY. Poor crop establishment is a major problem in edamame (Glycine max), a specialty type of soybean produced in locations throughout the United States. The objective of this research was to quantify the extent to which seed treatment with fludioxonil + mefenoxam improves seedling emergence of edamame. Emergence characteristics of fludioxonil + mefenoxam-treated and nontreated seed of $\mathbf{3 0}$ cultivars were characterized in field conditions over 2 years. Edamame cultivars used in the study exhibited poor field emergence in a previous study despite high germinability. Seed treatment with fludioxonil + mefenoxam at 2.5 and $3.75 \mathrm{~g} /$ $100 \mathrm{~kg}$ seed, respectively, improved crop emergence $33 \%$ to $47 \%$ more than the nontreated control. The emergence rate (days to $50 \%$ emergence) was improved the most by the seed treatment for several cultivars that were generally slow to emerge. Crop establishment is essential for further development of domestic edamame production. Seed treatment with fludioxonil + mefenoxam, at the rate currently registered for use on grain-type soybean, offers one approach to help vegetable growers improve edamame seedling emergence.
\end{abstract}

$\mathrm{E}$ damame, also known as vegetable soybean, is a specialty type of soybean harvested for human consumption at an immature seed stage. Edamame produces large seeds $(>20 \mathrm{~g} / 100$ seeds $)$ that have a sweet, nutty flavor. Traditionally a crop produced and consumed in East Asia, edamame has grown in popularity among American consumers (Sams et al., 2012). Certain barriers to domestic edamame production have been removed recently, such as the registration of several herbicides for preemergence and postemergence weed control (Williams and Nelson, 2014). Nonetheless, research and development to improve edamame production pales in comparison with grain-type soybean, for which the United States cultivates on some 83 million acres [U.S.

$\overline{\text { We thank Nick Hausman, Jim Moody, and the many }}$ students who assisted with this research.

Mention of a trademark, proprietary product, or vendor does not constitute a guarantee or warranty of the product by the U.S. Department of Agriculture and does not imply its approval to the exclusion of other products or vendors that may also be suitable.

${ }^{1}$ U.S. Department of Agriculture-Agricultural Research Service, Global Change and Photosynthesis Research, 1102 South Goodwin Avenue, Urbana, IL 61801

${ }^{2}$ Department of Plant Pathology, University of Kentucky, 1205 Hopkinsville Street, Princeton, KY 42445

${ }^{3}$ Corresponding author. E-mail: martin.williams@ars. usda.gov.

doi: 10.21273/HORTTECH03888-17
Department of Agriculture (USDA), 2016].

Poor crop establishment is a major problem in edamame. Poor seedling emergence and uneven crop stands appear to be the norm in field trials, from North Dakota (Duppong and Hatterman-Valenti, 2005) to Georgia (Rao et al., 2002), in Illinois (Williams, 2015b) and Pennsylvania (Sánchez et al., 2005). Using 136 edamame entries over a 3-year period, high germination of seed lots failed to account for poor seedling emergence (Williams, 2015b). Because of limited research, edamame is often grown using agronomic practices employed in grain-type soybean production, with limited knowledge of the appropriateness of such approaches (Williams, 2015a; Zhang et al., 2013).

Seedling diseases of soybean caused by soilborne fungal and oomycete pathogens, such as Fusarium species, Phytophthora sojae, Pythium species, and Rhizoctonia solani, are not uncommon and caused estimated annual yield losses averaging $11,749,000$ $\mathrm{Mg}$ in North America grain-type soybean between 2010 and 2014 (Allen et al., 2017). Seedling diseases can lead to poor crop establishment in soybean and can be managed with fungicide seed treatments (Bradley, 2008; Dorrance and McClure, 2001; Dorrance et al., 2003). Fungicides with broad-spectrum activity on fungi and oomycetes provide the best level of seedling disease management. A fungicide that has been commonly used as a seed treatment on soybean with activity against Fusarium species and $R$. solani is fludioxonil (Broders et al., 2007b; Dorrance et al., 2003; Munkvold and O'Mara, 2002). Mefenoxam or the related compound metalayxl has often been used as a seed treatment on soybean to manage seedling diseases caused by oomycete pathogens $P$. sojae and Pythium species (Broders et al., 2007a; Dorrance and McClure, 2001; Dorrance et al., 2004). A mixture of fludioxonil + mefenoxam is currently registered for use on graintype soybean as well as several other legume crops.

The objective of this research was to quantify the extent to which seed treatment with fludioxonil + mefenoxam improves seedling emergence of edamame.

\section{Materials and methods}

Germplasm. Edamame cultivars were obtained from two public and four private sources (Table 1). Cultivars were selected from a list of 136 entries tested in a previous research (Williams, 2015b), which showed high seed germination (up to $99 \%$ ) in controlled conditions, yet inadequate $(<50 \%)$ seedling emergence in the field. In addition, a widely used grain-type cultivar, Asgrow AG-3253 (Monsanto, St. Louis, MO), was included as a control.

Experimental approach. Field experiments were conducted at the

\begin{tabular}{llll}
\hline $\begin{array}{l}\text { Units } \\
\text { To convert U.S. to SI, } \\
\text { multiply by }\end{array}$ & U.S. unit & SI unit & $\begin{array}{l}\text { To convert SI to U.S., } \\
\text { multiply by }\end{array}$ \\
\hline 0.3048 & $\mathrm{ft}$ & $\mathrm{m}$ & 3.2808 \\
2.54 & inch $(\mathrm{es})$ & $\mathrm{cm}$ & 0.3937 \\
1.1209 & $\mathrm{lb} / \mathrm{acre}$ & $\mathrm{kg} \cdot \mathrm{ha}^{-1}$ & 0.8922 \\
28.3495 & $\mathrm{oz}$ & $\mathrm{g}$ & 0.0353 \\
62.5000 & $\mathrm{oz} / 100 \mathrm{lb}$ & $\mathrm{g} / 100 \mathrm{~kg}$ & 0.0160 \\
0.9072 & $\mathrm{ton}(\mathrm{s})$ & $\mathrm{mg}$ & 1.1023 \\
$\left({ }^{\circ} \mathrm{F}-32\right) \div 1.8$ & ${ }^{\circ} \mathrm{F}$ & ${ }^{\circ} \mathrm{C}$ & $\left({ }^{\circ} \mathrm{C} \times 1.8\right)+32$
\end{tabular}


Table 1. Soybean cultivar, type, 100-seed weight, germination, and seed source of germplasm used in field emergence experiments.

\begin{tabular}{|c|c|c|c|c|}
\hline Cultivar & Type & 100 -seed wt $(\mathrm{g})^{\mathrm{z}}$ & Germination (\%) & Source \\
\hline Asgrow AG-3253 & Grain & 18.6 & 99.5 & Monsanto \\
\hline Agate & Edamame & 25.2 & 65.0 & USDA Soybean Germplasm Collection \\
\hline Asmara & Edamame & 16.9 & 91.5 & USDA Soybean Germplasm Collection \\
\hline Bellesoy & Edamame & 8.9 & 86.5 & Wannamaker Seeds, Saluda, NC \\
\hline BeSweet 2015 & Edamame & 30.9 & 95.0 & Rupp Seeds, Wauseon, OH \\
\hline Butterbean & Edamame & 17.4 & 95.5 & Johnny's Selected Seeds, Winslow, ME \\
\hline Early Hakucho & Edamame & 22.1 & 97.5 & USDA Soybean Germplasm Collection \\
\hline Eda Mame Uase Chaurame & Edamame & 21.0 & 98.5 & USDA Soybean Germplasm Collection \\
\hline Fiskeby III & Edamame & 19.2 & 95.5 & USDA Soybean Germplasm Collection \\
\hline Fuji & Edamame & 14.2 & 65.5 & USDA Soybean Germplasm Collection \\
\hline Gardensoy 01 & Edamame & 23.6 & 95.0 & University of Illinois Urbana-Champaign \\
\hline Gardensoy 41 & Edamame & 32.7 & 95.5 & University of Illinois Urbana-Champaign \\
\hline Gardensoy 43 & Edamame & 19.8 & 93.0 & University of Illinois Urbana-Champaign \\
\hline Kaohsiung 1 & Edamame & 27.8 & 88.5 & USDA Soybean Germplasm Collection \\
\hline Kegon & Edamame & 25.0 & 95.0 & USDA Soybean Germplasm Collection \\
\hline Komagi dadacha & Edamame & 20.4 & 84.5 & USDA Soybean Germplasm Collection \\
\hline Miyagi shirome & Edamame & 17.1 & 96.5 & USDA Soybean Germplasm Collection \\
\hline Okuhara daizu & Edamame & 22.2 & 95.0 & USDA Soybean Germplasm Collection \\
\hline Randolph & Edamame & 20.2 & 86.0 & USDA Soybean Germplasm Collection \\
\hline Taiwame & Edamame & 31.2 & 87.0 & Evergreen Seed \\
\hline Tambagura & Edamame & 22.9 & 77.5 & USDA Soybean Germplasm Collection \\
\hline Ware & Edamame & 17.2 & 95.5 & USDA Soybean Germplasm Collection \\
\hline
\end{tabular}

${ }^{\mathrm{z}} \mathrm{lg}=0.0353 \mathrm{oz}$.

University of Illinois Vegetable Crop Farm near Urbana, IL, in 2014 and 2015. The soil was a Flanagan silt loam (fine, smectitic, and mesic Aquic Argiudolls) averaging 3.1\% organic matter and a $\mathrm{pH}$ of 6.3 . Experiments followed the soybean year of a sweet corn (Zea mays)soybean rotation. Before planting, fields were prepared using two passes of a field cultivator. Planting dates were 21 May 2014 and 27 May 2015. Planting depth was 1.2 inches. Within $1 \mathrm{~d}$ of planting, $S$-metolachlor was applied at a rate of $1.6 \mathrm{lb} /$ acre across the experimental site for preemergence weed control.

The treatment design was a factorial arrangement of cultivars and seed treatments. The seed treatment factor had two levels: none and treatment with fludioxonil + mefenoxam at the rate currently registered for use on grain-type soybean. Seeds were treated with fludioxonil + mefenoxam (ApronMaxx RTA; Syngenta Crop

Table 2. The main effect of seed treatment (fludioxonil + mefenoxam at 2.5 and $3.75 \mathrm{~g} / 100 \mathrm{~kg}$ seed, respectively) on soybean emergence at 1,2 , and 3 weeks after planting (WAP) across 29 edamame cultivars and one grain-type cultivar. ${ }^{\mathrm{z}}$

\begin{tabular}{lccc}
\hline & 1 WAP & 2 WAP & 3 WAP \\
\cline { 2 - 4 } Seed treatment & $9 \mathrm{~b}^{\mathrm{y}}$ & Emergence (\%) & \\
\hline None & $13 \mathrm{a}$ & $38 \mathrm{~b}$ & $42 \mathrm{~b}$ \\
Fludioxonil + mefenoxam & $51 \mathrm{a}$ & $57 \mathrm{a}$ \\
\hline
\end{tabular}

${ }^{{ }^{2}} 1 \mathrm{~g} / 100 \mathrm{~kg}=0.0160 \mathrm{oz} / 100 \mathrm{lb}$.

${ }^{y}$ Means within a column followed by a different letter are different based on the type 3 test of fixed effects $(P<0.05)$.

Protection, Greensboro, NC) at a rate of $5.0 \mathrm{fl} \mathrm{oz} / 100 \mathrm{lb}$ seed (fludioxonil + mefenoxam at 2.5 and $3.75 \mathrm{~g} / 100 \mathrm{~kg}$ seed, respectively).

The experimental design was a split plot with three replications. Cultivars were assigned to main plots consisting of two rows planted with 50 seeds/row over a length of $8.0 \mathrm{ft}$. The levels of seed treatment were applied to single-row subplots, such that treated and nontreated seed of each cultivar were adjacent to one another in each replicate.
Data collection. Weight of 100 seeds of each cultivar and germinability were determined before planting. A total of 100 seeds per cultivar were incubated on a distilled water-moistened germination paper at $70{ }^{\circ} \mathrm{F}$ and $90 \%$ relative humidity. Germinated seedlings were counted and removed daily until germination ceased within $10 \mathrm{~d}$. In field trials, a seedling was considered emerged when its cotyledons were aboveground and completely free of soil surface contact. Emergence counts were 

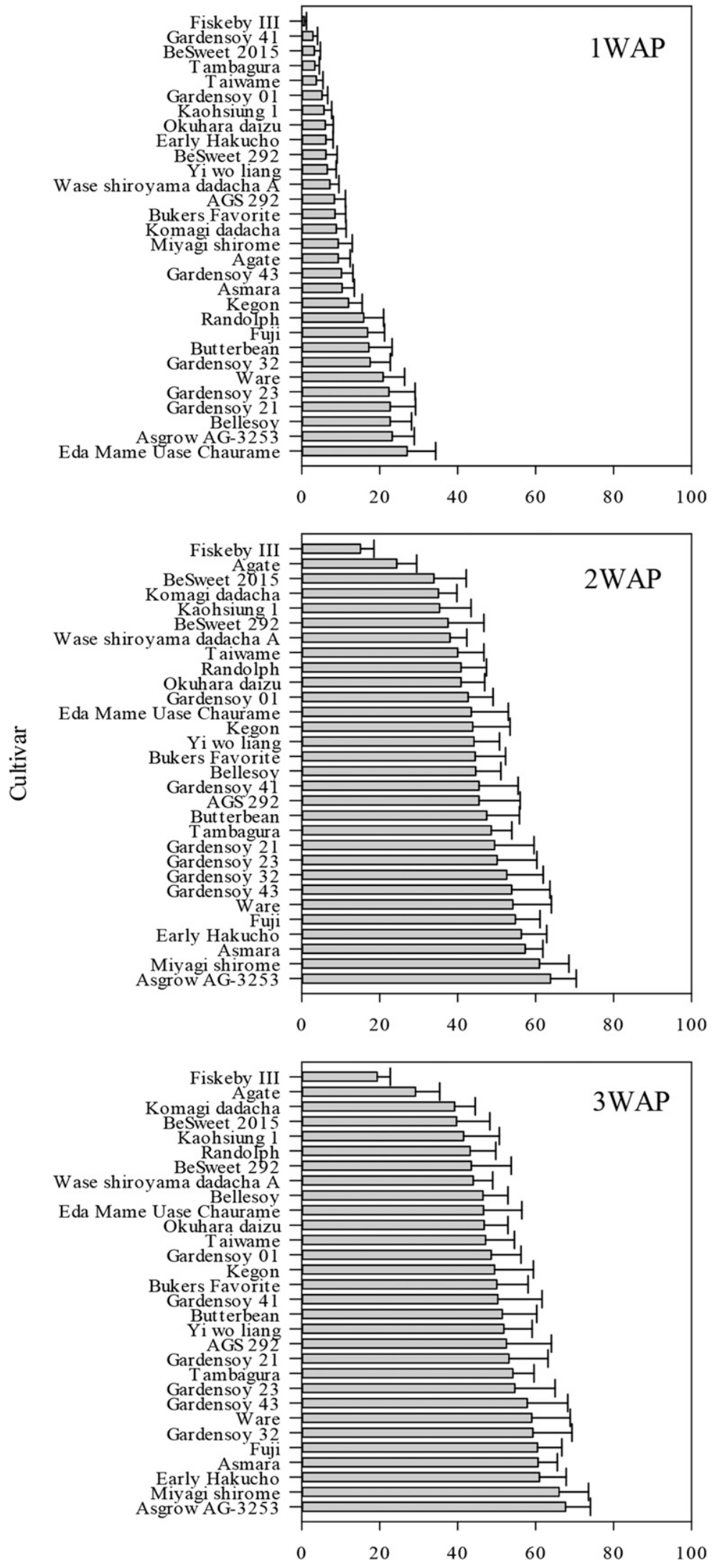

Emergence (\%)

Fig. 1. The main effect of soybean cultivar ( 29 edamame cultivars and one graintype cultivar) on emergence at 1, 2, and 3 weeks after planting (WAP). Error bars are SE. made daily until one-half of planted seeds emerged. In addition, emerged seedlings were counted 1,2 , and 3 weeks after planting (WAP). No seedlings emerged 3 WAP. These data were used to determine time from planting to $50 \%$ emergence.

Data Analysis. The visual examination of residuals indicated crop emergence 2 and 3 WAP met assumptions of homoscedasticity and normality after arc-sine transformation, whereas other response variables met analysis of variance assumptions without transformation. To determine the effect of cultivar, seed treatment, and their interaction on crop emergence, data were analyzed using the mixed procedure of SAS (version 9.3; SAS Institute, Cary, NC). Fixed effects included cultivar, seed treatment, and their interaction. Random effects included year and replicate nested within year. Nontransformed means and standard errors are presented for ease of interpretation. In addition, linear associations between crop response variables were quantified using Bonferroni-corrected correlation coefficients. Analyses were declared significant at $P<0.05$.

\section{Results}

ENVIRONMENTAL CONDITIONS. Postplanting weather was a characteristic of the variable growing conditions in the midwestern U.S. The 2014 trial experienced suboptimal edaphic conditions during crop emergence. Soil crusting was observed, likely the result of 1.0 inch of rainfall occurring in a short period immediately after planting, followed by conditions favoring rapid evapotranspiration with no additional rainfall for 1 week (data not shown). By contrast, the 2015 trial experienced favorable conditions for several weeks after planting. After planting into a moist seedbed, rainfall occurred $4 \mathrm{~d}$ after planting and on a regular basis for 3 weeks. As a result, the soil surface largely remained moist and loose during the study.

Crop emergence. Soil conditions in 2014 likely delayed crop emergence compared with 2015 . For instance, average emergence 2 WAP was $24 \%$ and $66 \%$ in 2014 and 2015 , respectively. Nonetheless, rank order of cultivar emergence was relatively consistent, with the graintype cultivar (Asgrow AG-3253) and edamame cultivar Miyagi shirome 
(USDA Soybean Germplasm Collection, Urbana, IL) among the highest emerging cultivars, whereas edamame cultivars Agate and Fiskeby III (USDA Soybean Germplasm Collection) were among the lowest emerging cultivars (data not shown).

Seed treatment affected crop emergence both years at all sampling times $(P<0.001)$. Seed treatment with fludioxonil + mefenoxam improved crop emergence $33 \%$ to $47 \%$ more than the nontreated control. For instance at $3 \mathrm{WAP}$, the nonemergence compared with $57 \%$ emergence in the fludioxonil + mefenoxam treatment (Table 2).

The main effect of cultivar also affected crop emergence at all sampling times $(P<0.001)$. The grain-type treated control averaged $42 \%$ crop

cultivar Asgrow AG-3253 was among the highest emerging cultivars tested, averaging $23 \%, 64 \%$, and $68 \%$ emergence at 1,2 , and 3 WAP (Fig. 1). By contrast, 'Fiskeby III' was the lowest emerging cultivar, averaging $1 \%, 15 \%$, and $19 \%$ emergence at 1,2 , and 3 WAP.

Cultivar and seed treatment had an interactive effect only on emergence rate $(P=0.004)$. Most earlyemerging cultivars (e.g., less than $9 \mathrm{~d}$ to $50 \%$ emergence) showed similar emergence rates between treated and nontreated seed (Fig. 2). However, several later-emerging cultivars benefited from seed treatment with fludioxonil + mefenoxam. For example, time to reach $50 \%$ emergence was $17 \mathrm{~d}$ for nontreated seed of edamame cultivar Taiwame (Evergreen Seed,

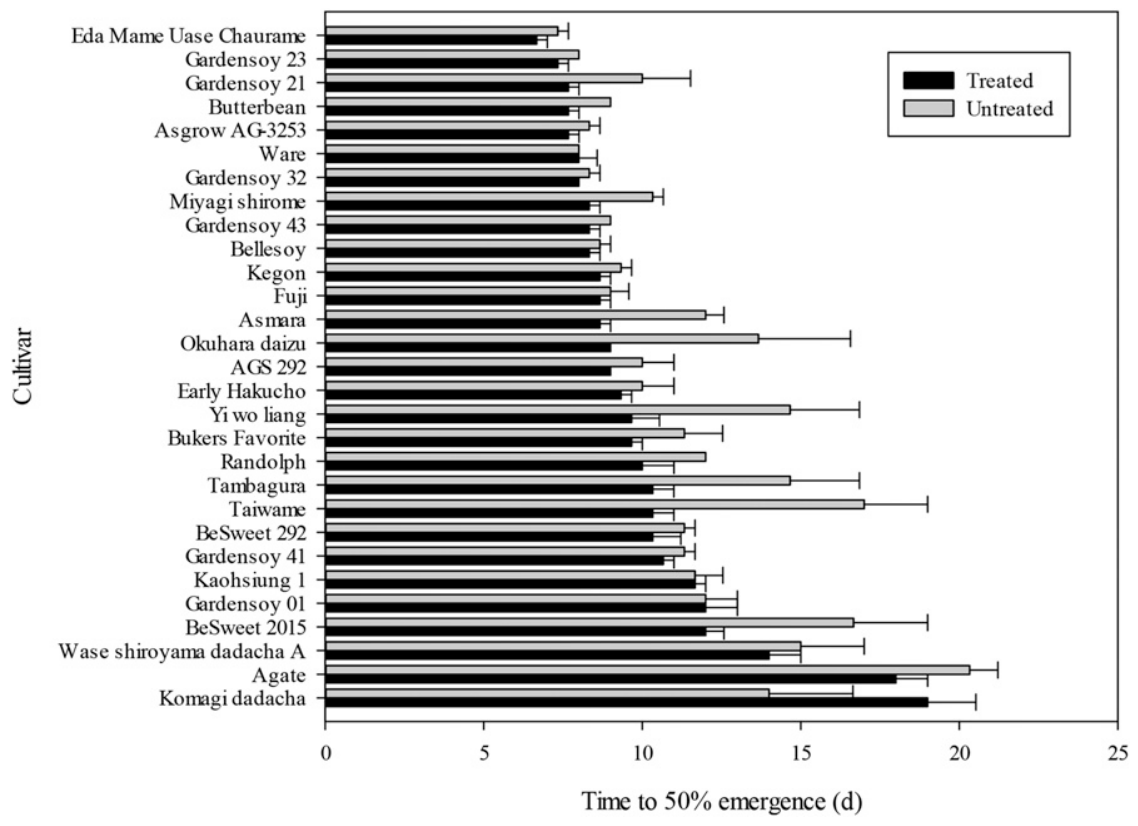

Fig. 2. The interactive effect of soybean cultivar (29 edamame cultivars and one grain-type cultivar) and seed treatment [fludioxonil + mefenoxam $(2.5$ and $3.75 \mathrm{~g} / 100 \mathrm{~kg}$ seed, respectively) or nontreated] on time to $50 \%$ emergence (d). Cultivar Fiskeby III was not included because of $<\mathbf{5 0 \%}$ emergence. Error bars are $\mathrm{SE} ; 1 \mathrm{~g} / 100 \mathrm{~kg}=0.0160 \mathrm{oz} / 100 \mathrm{lb}$.
Anaheim, CA), whereas only $10 \mathrm{~d}$ were needed for treated Taiwame seed.

Most response variables were associated. Weight of 100 seeds was negatively correlated with emergence 1 WAP [correlation coefficient $(\rho)=$ -0.23 ] and 2 WAP $(\rho=-0.52)$, yet positively correlated $(\rho=0.40)$ with time to $50 \%$ emergence (Table 3 ). Germination was positively correlated with emergence $2(\rho=0.32)$ and 3 WAP $(\rho=0.30)$. Time to $50 \%$ emergence was negatively correlated with germination and emergence at all three sampling times $(\rho \leq-0.32)$. Weight of 100 seeds was not associated with germination.

\section{Discussion}

Emergence of most edamame cultivars was poorer than the graintype control. Williams (2015b) reported similar findings in a survey of soybean germplasm, whereby mean emergence of 136 edamame lines was $11 \%$ to $24 \%$ lower than 14 grain-type entries. The grain-type control used in this study, 'Asgrow AG-3253', is adapted for use in Illinois and has genes conferring resistance to soybean cyst nematode [Heterodera glycines (gene MR3)] and phytophthora root and stem rot [caused by $P$. sojae (gene RpsIc)] (Monsanto, 2015). By contrast, the extent to which these edamame cultivars are resistant to soil pathogens or adapted to the location is unknown.

Larger-seeded cultivars generally took longer to emerge and had lower emergence than smaller-seeded cultivars. Factors driving such a response have not been elucidated. Generally, grain-type cultivars have seed weight $<20 \mathrm{~g} / 100$ seeds, and under these conditions, "large" seed have exhibited greater seedling vigor than "small" seed (Burris et al., 1971; Place et al., 2011), even under simulated soil compaction (Longer et al., 1986).

Table 3. Bonferroni-corrected correlation coefficients ( $\rho$ ) between soybean seed and emergence traits at 1,2 , and 3 weeks after planting (WAP) and time to $50 \%$ emergence across 29 edamame cultivars and one grain-type cultivar.

\begin{tabular}{|c|c|c|c|c|c|}
\hline & Germination & Emergence $1 \mathrm{WAP}$ & Emergence 2 WAP & Emergence 3 WAP & Time to $50 \%$ emergence \\
\hline & \multicolumn{5}{|c|}{ Correlation coefficient } \\
\hline 100-seed weight & 0.11 & $-0.52 *$ & $-0.23^{*}$ & -0.12 & $0.40^{*}$ \\
\hline Emergence $1 \mathrm{WAP}$ & - & - & $0.44^{*}$ & $0.35^{*}$ & $-0.56^{*}$ \\
\hline Emergence 2 WAP & - & - & - & $0.94 *$ & -0.82 * \\
\hline Emergence $3 \mathrm{WAP}$ & - & - & - & - & $-0.77^{*}$ \\
\hline
\end{tabular}

${ }^{*} P<0.05$. 
Although edamame cultivars used in this work varied in seed size, the vegetable industry prefers seed sizes $>20 \mathrm{~g} /$ 100 seeds (Rao et al., 2002). Considering industry preference for larger seed, it is interesting that seedling emergence declined for the largest seed size class of exceptionally large lines (>22 g/100 seeds), presumably because of greater soil resistance on the large seed (Burris et al., 1973).

Seed treatment with fludioxonil + mefenoxam improved edamame seedling emergence. In a rolled towel assay, seed treatment with fludioxonil + mefenoxam at $3.75+2.5 \mathrm{~g} / 100$ $\mathrm{kg}$ seed, respectively, failed to reduce symptoms caused by Fusarium graminearum infection of soybean seedlings (Ellis et al., 2011). In a potted greenhouse experiment inoculated with $P$. sojae, seed treatment with mefenoxam at $3.75 \mathrm{~g} / 100 \mathrm{~kg}$ of seed improved emergence and seedling growth of a soybean cultivar with partial resistance to the pathogen (Dorrance and McClure, 2001). In field trials conducted in North Dakota, fludioxonil + mefenoxam significantly improved soybean stand establishment and yields at locations in which soybean planting was followed by cool, wet conditions (Bradley, 2008). By comparison, field experiments in New York showed seed treatment with fludioxinil + insecticide combinations did not affect soybean establishment compared with the nontreated control (Cox et al., 2008). Uneven inoculum distribution and variable environmental conditions complicate field-testing of fungicide seed treatment efficacy (Dorrance and McClure, 2001). That an emergencemediated improvement from fludioxonil + mefenoxam in the present work was detected across two variable field environments reflects the robust nature of the seed treatment contribution to seedling emergence. Further research is needed to identify exactly which pathogens are involved in seedling blight of edamame. Conceivably, seedling disease pathogens of edamame may be the same pathogens of grain-type soybean, including Fusarium species, P. sojae, Pythium species, and $R$. solani (Koenning and Wrather, 2010).

Rapid, uniform crop emergence after planting is desirable for maximizing soybean productivity. Improvements in edamame emergence are likely to come from multiple tactics. Recent work by
Crawford (2017) showed edamame is more susceptible to planting depth than grain-type soybean. Effort among the U.S. edamame breeding programs to produce high quality seed and to introduce genes conferring resistance to common soybean diseases would be beneficial. In the meantime, under the conditions of this work, seed treatment with fludioxonil + mefenoxam offered an immediate approach to improve seedling establishment. In addition, the emergence rate was improved the most by the seed treatment for several cultivars that were generally slow to emerge. The extent to which such improvements in crop emergence influence crop yield merits study. Nonetheless, crop establishment is essential for the development of viable edamame production in the U.S. Seed treatment with fludioxonil + mefenoxam, at the rate currently registered for use on grain-type soybean, offers one approach to help vegetable growers improve crop emergence.

\section{Literature cited}

Allen, T.W., C.A. Bradley, A.J. Sisson, E. Byamukama, M.I. Chilvers, C.M. Coker, A.A. Collins, J.P. Damicone, A.E. Dorrance, N.S. Dufault, P.D. Esker, T.R. Faske, L.J. Giesler, A.P. Grybauskas, D.E. Hershman, C. A. Hollier, T. Isakeit, D.J. Jardine, H.M. Kelly, R.C. Kemerait, N.M. Cleczewski, S.R. Koenning, J.E. Kurle, D.K. Malvick, S.G. Markell, H.L. Mehl, D.S. Mueller, J.D. Mueller, R.P. Mulrooney, B.D. Nelson, M.A. Newman, L. Osborne, C. Overstreet, G.B. Padgett, P.M. Phipps, P.P. Price, E.J. Sikora, D.L. Smith, T.N. Spurlock, C.A. Tande, A.U. Tenuta, K.A. Wise, and J.A. Wrather. 2017. Soybean yield loss estimates due to diseases in the United States and Ontario, Canada from 2010 to 2014. Plant Health Prog., doi: 10.1094/PHPRS-16-0066.

Bradley, C.A. 2008. Effect of fungicide seed treatments on stand establishment, seedling disease, and yield of soybean in North Dakota. Plant Dis. 92:120-125.

Broders, K.D., P.E. Lipps, P.A. Paul, and A.E. Dorrance. 2007a. Characterization of Pythium spp. associated with corn and soybean seed and seedling disease in Ohio. Plant Dis. 91:727-735.

Broders, K.D., P.E. Lipps, P.A. Paul, and A.E. Dorrance. 2007b. Evaluation of Fusarium graminearum associated with corn and soybean seed and seedling disease in Ohio. Plant Dis. 91:1155-1160.

Burris, J.S., O.T. Edje, and A.H. Wahab. 1973. Effects of seed size on seedling performance in soybeans: II. Seedling growth and photosynthesis and field performance. Crop Sci. 13:207-210.

Burris, J.S., A.H. Wahab, and O.T. Edje. 1971. Effects of seed size on seedling performance in soybeans. I. Seedling growth and respiration in the dark. Crop Sci. 11:492-496.

Crawford, L.E. 2017. Production factors to improve edamame emergence and crop competitiveness with weeds. Univ. Illinois, Urbana, IL, MS Diss.

Cox, W.J., E. Shields, and J.H. Cherney. 2008. Planting date and seed treatment effects on soybean in the northeastern United States. Agron. J. 100:1662-1665.

Dorrance, A.E., S.A. Berry, P. Bowen, and P.E. Lipps. 2004. Characterization of Pythium spp. from three Ohio fields for pathogenicity on corn and soybean and metalaxyl sensitivity. Plant Health Prog. doi: 10.1094/PHPH-2004-0202-01-RS.

Dorrance, A.E., M.D. Kleinhenz, S.A. McClure, and N.T. Tuttle. 2003. Temperature, moisture, and seed treatment effects on Rhizoctonia solani root rot of soybean. Plant Dis. 87:533-538.

Dorrance, A.E. and S.A. McClure. 2001. Beneficial effects of fungicide seed treatments for soybean cultivars with partial resistance to Phytophthora sojae. Plant Dis. 85:1063-1068.

Duppong, L.M. and H. HattermanValenti. 2005. Yield and quality of vegetable soybean cultivars for production in North Dakota. HortTechnology 15:896-900.

Ellis, M.L., K.D. Broders, P.A. Paul, and A.E. Dorrance. 2011. Infection of soybean seed by Fusarium graminearum and effect of seed treatments on disease under controlled conditions. Plant Dis. 95:401407.

Koenning, S.R. and J.A. Wrather. 2010. Suppression of soybean yield potential in the continental United States by plant diseases from 2006 to 2009. Plant Health Prog. doi: 10.1094/PHP-2010-112201-RS.

Longer, D.E., E.J. Lorenz, and J.T. Cothren. 1986. The influence of seed size on soybean [Glycine $\max$ (L.) Merrill] emergence under simulated soil crust conditions. Field Crops Res. 14:371-375.

Monsanto. 2015. National product profile AG3533. 3 Nov. 2017. <http:// www.agseedselect.com/product-profile/ national/5E9NUR2XF>.

Munkvold, G.P. and J.K. O’Mara. 2002. Laboratory and growth chamber evaluation of fungicidal seed treatments for maize seedling blight caused by Fusarium species. Plant Dis. 86:143-150. 
Place, G.T., S.C. Reberg-Horton, T.E. Carter, Jr., and A.N. Smith. 2011. Effects of soybean seed size on weed competition. Agron. J. 103:175-181.

Rao, M.S.S., A.S. Bhagsari, and A.I. Mohamed. 2002. Fresh green seed yield and seed nutritional traits of vegetable soybean genotypes. Crop Sci. 42:19501958.

Sams, C.E., V.R. Pantalone, D.A. Kopsell, S. Zivanovic, and D.E. Deyton. 2012. Edamame: A potential high value crop for growers. Proc. Mid-Atlantic Fruit Veg. Convention, Hershey, PA.
Sánchez, E., K. Kelley, and L. Butler. 2005. Edamame production as influenced by seedling emergence and plant population. HortTechnology 15:672-676.

U.S. Department of Agriculture. 2016. Statistics by subject. 3 Oct. 2017. <http://www.nass.usda.gov/Statistics_ by_Subject/index.php? sector=CROPS $>$.

Williams, M.M., II. 2015a. Managing weeds in commercial edamame production: Current options and implications. Weed Sci. 63:954-961.

Williams, M.M., II. 2015b. Phenomorphological characterization of vegetable soybean germplasm lines for commercial production. Crop Sci. 55:1274-1279.

Williams, M.M., II., and R.L. Nelson. 2014. Vegetable soybean tolerance to bentazon, fomesafen, imazamox, linuron, and sulfentrazone. Weed Technol. 28:601-607.

Zhang, Q.Y., M. Hashemi, S.J. Hebert, and Y.S. Li. 2013. Different responses of preemergence and early seedling growth to planting depth between vegetable soybean and grain soybeans. Legume Res. 36:515-521. 